\title{
LEGAL WRITING: SOME TOOLS
}

\section{THE Right HONOURABle BEVERLEy MCLACHLIN*}

I am both honoured and delighted to speak here this evening. First because this address brings me back to my home province of Alberta, and second because it gives me the opportunity to recognize the Alberta Law Review and those who have contributed to its success. Like its companion publications across Canada, the Review is a vital source of analysis of the complex issues facing our legal system. The Review enhances the quality of justice in this country by contributing to a reasoned analysis of these issues. And beyond its legal analysis, the Review gives scholars the chance to write and publish and offers students the opportunity to hone their research, analytical, and writing skills.

Tonight I would like to talk to you about the last of these skills - the skill of legal writing. I begin with a preliminary question: Does legal writing still matter in the electronic age? The answer, it seems to me, is an unequivocal yes.

The law students here tonight have grown up in the information and communication age. In your lifetimes, computers have become part of the fabric of the workplace. Fax machines hastened the flow of information around the globe, only to be superseded by the even more powerful technologies of the Internet. Cell phones ring almost everywhere and at any time. These advances in technology and communications have brought us many benefits, speed being the most evident.

But we cannot rely on communications technology to ensure the quality of communication. In fact, speed often has the opposite effect. Amidst all these technological advances, clear, concise, and organized legal writing remains the foundation of good advocacy. Technology cannot ensure that the language is clear, concisely phrased or logically organized, although it can sometimes be harnessed to help. Effective legal writing remains essential, whether we are writing to clients, preparing articles for law reviews or organizing factums for appeal courts. Emerson once said that it is a luxury to be understood. For lawyers, it goes beyond that. Being understood is a necessity. So yes, good legal writing does matter. Lawyers, legal scholars, and judges work through words. Words are our tools. We should use them effectively. It does not serve the courts, the public or the profession to persist with language that only lawyers can understand.

This answer leads us to a second question: Do lawyers and judges use words well? Here my answer must be more equivocal. Sadly, our reputation is far from shining. Too often our critics accuse us of wallowing in arcane language. They say - to use a phrase worthy of lawyers - that we cherish obfuscation. They refer to convoluted language as the secret handshake of the profession, going on to point out that the legal profession is not supposed to be a secret society.

P.C., Chief Justice of Canada. This article is a version of Justice McLachlin's speech at the annual Alberla Law Review Banquet, held at the Hotel MacDonald in Edmonton, Alberta, 28 February 2001. 
Mavor Moore, the respected Canadian playwright and producer, once gently - but with more than a grain of truth - chided lawyers for intentionally perpetuating such foggy language:

\author{
The lawyer is your friend because \\ He guides you through the maze of laws. \\ In fact we write them round about \\ So only we can make them out.'
}

Of course, many lawyers write well. Yet too little time too often forces us to pay too little attention to good legal writing. We see our profession as legal, not editorial. Yet we could not be more wrong. Well-written briefs are critical to effective advocacy and wellwritten judgments essential to the application and development of the law. Plain English, logically organized and clearly expressed, will make your argument far better and any judgment more useful.

Appellate judges see an almost endless supply of legal writing in the factums before them. The quality of that writing varies greatly. Sometimes it is clear, concise, and forceful. Too often it is muddled, convoluted and tentative, peppered with "hereinafter," "generally," "subject to," and similar jargon that gets in the way of communication. Although judges try to address the merits of a case, not the writing skills of counsel, poor writing can prevent judges from grasping the legal subtleties that counsel is trying to express.

If lawyers often fail to write well, the same is true of judges. Judges are aware as never before about the importance of clear, concise judgments that offer succinct guidance on legal principle. For years now, Canadian judges have been attending courses on judgment writing. We began by tapping the American interest in the special challenges of judgment writing, and now we have our own experts in the field. Yet too often the complexity of the subject matter and the law, coupled with the pressures of time, overwhelm the judges' good intentions to write clearly, simply, and concisely.

So, sadly, the answer to the question "Do lawyers and judges write well?" is still too often "No." As a critic once stated, "[t]here are two things wrong with almost all legal writing. One is its style. The other is its content." While the phrase brings a chuckle, it still rings all too true.

This brings us to a third question: How can we improve our legal writing? We can start by reminding ourselves continually of the need to master the elementary, but oft neglected, rules of good legal writing. Before you reach the Supreme Court - or any other court or forum where you apply your advocacy skills - remind yourself that the basic rules of good writing are as essential an element of your skills as the power of your intellect and the force of your legal reasoning.

$2 \quad$ F. Rodell, "Goodbye to Law Reviews" (1936) 23 Va. L. Rev. 38 at 38. 
I cannot hope tonight to set out all the rules for effective legal writing - even if I knew them - and I strongly suspect that you would not want me to if I could. However, perhaps we can look at a few of the core considerations in good legal writing. Most are simply the rules of effective writing in general.

The widely respected and highly readable British current affairs magazine, The Economist, reminds us in its Pocket Style Book that, "Clear thinking is, in fact, the key to clear writing." ${ }^{3}$ Writing is not simply the random recording of thoughts. Writing cannot be clear without mental organization. Equally, trying to rid a text of its redundancies, verbosity and excruciating structure will often expose the confusion of an argument. Writing clearly, and rewriting, offers you a chance to rethink your strategy before it falters in court. Sometimes lawyers know how to write but resort to unclear writing to hide muddy thinking. They will eventually be found out. Better to rethink the strategy and rephrase the writing than to enter court hoping the judges will not detect that your murky writing is a smokescreen for a poor argument.

George Orwell observed that a scrupulous writer will ask at least four questions in writing every sentence: "What am I trying to say? What words will express it? What image or idiom will make it clearer? Is this image fresh enough to have an effect?" And, said Orwell, the writer will probably ask two more: "Could I put it more shortly? Have I said anything that is avoidably ugly?"4

In his essay, "Politics and the English Language" (1946), Orwell proposed six elementary rules of writing:

(i) Never use a metaphor, simile or other figure of speech which you are used to seeing in print.

(ii) Never use a long word where a short word will do.

(iii) If it is possible to cut out a word, always cut it out.

(iv) Never use the passive where you can use the active.

(v) Never use a foreign phrase, a scientific word or a jargon word if you can think of an everyday English equivalent. [Let this in particular be a reminder to those lawyers who still spout Latin when English will do just as well].

(vi) Break any of these rules sooner than saying anything outright barbarous. ${ }^{5}$

Yet lawyers often ignore these basic rules. Their - shall I say our - prose is notorious for three cardinal sins. The first - and perhaps the worst - cardinal sin is verbosity. The good artisan knows which tool to use for which task. But we lawyers, the

The Economist Pocket Style Book (London: Economist Publications, 1986) at xi.

- G. Orwell, "Politics and the English Language" in Collected Essays (London: Secker \& Warburg, 1961) 353 at 362.

$s \quad$ lbid. at 366-67. 
craftsmen of words, like to use every instrument in the toolbox. In Plain English for Lawyers, American lawyer Richard Wydick argues that we often use many words to say what could be said in a few:

We use arcane phrases to express commonplace ideas. Seeking to be precise, we become redundant. Seeking to be cautious, we become verbose. Our sentences twist on, phrase within clause within clause, glazing the eyes and numbing the minds of our readers. The result is a writing style that has, according to one critic, four outstanding characteristics. It is "(1) wordy, (2) unclear, (3) pompous, and (4) dull."”

A lot of the wordiness that mars legal writing is related to the use of what Wydick calls "arcane phrases." Some lawyers might feel less than whole if they cannot dress their writing in words and phrases that have traditionally provided so much comfort for the profession, and so much confusion for everyone else. But "hereinafter," "subsequent to," "utilize," "inter alia," "until such time as," and "notwithstanding the fact that" will not win the hearts or minds of the judiciary. These phrases may make you sound like a lawyer to an uniformed public, although they will do little to inform the public. They certainly will not impress a court.

Redundant legal phrases get in the way of communication. "Cease and desist," "due and payable," and "good and sufficient" are examples. Then comes the much abused expression "null and void." Wydick asks:

Why do lawyers use the term null and void? According to the dictionary, either null or void by itself would do the job. But the lawyer's pen seems impelled to write null and void, as though driven by primordial instinct. An occasional lawyer, perhaps believing that null and void looks naked by itself, will write totally null and void, or perhaps totally null and void and of no further force or effect whatsoever.?

Maybe lawyers who write like this still believe they are being paid by the word.

If using too many words takes first prize in the pantheon of legal writing sins, stringing them together in dull ways runs a close second. Lawyers love the passive voice. They think it gives objectivity to their statements. But taking the action out of writing does not add to its power. Quite the reverse. Lawyers should avoid the passive voice, and not only because Orwell disliked it. The passive voice saps text of its strength and hides too much. It continues to puzzle our critics that a profession that struggles for precision indulges so shamelessly in passive sentences. For example, the statement that "it was found that he lied" hides the identity of the person who decided. Why not be direct and informative?

Third prize in the catalogue of legal writing sins goes to nominalization. Justice John Laskin of the Ontario Court of Appeal criticizes the lawyer's penchant for changing verbs into nouns, ${ }^{8}$ and he is right. Action verbs bring prose to life, make it leap off the page. When you reduce the action to a thing, it just lies there, flat and unremarkable. Laskin

R. Wydick, Plain English For Lawyers, 4th ed. (Durham: Carolina Academic Press, 1998) at 3.

Ibid. at 19 [emphasis in original].

* J.I. Laskin, J.A., "Forget the Wind Up and Make the Pitch: Some Suggestions for Writing More Persuasive Factums" (August 1999) 18 Advocates' Soc. J. 3 at 10. 
goes so far as to call this a contagious disease among lawyers. So watch your nominalizations. "Instead of writing 'make an argument,' write 'argue,' instead of 'executed a veto,' write 'vetoed.",9

Of course there are a lot more legal writing sins. Robert Leflar, in a whimsical vein, lists a few:

1. Subjects and verb always has to agree.

2. Make each pronoun agree with their antecedent.

3. Just between you and I, case is important too.

4. Being bad grammar, the writer will not use dangling participles.

5. Parallel construction with coordinate conjunctions is not only an aid to clarity but also the mark of a good writer.

6. Join clauses good, like a conjunction should.

7. Don't write run-on sentences they are hard to read, you should punctuate.

8. Don't use no double negatives. Not never.

9. Mixed metaphors are a pain in the neck and ought to be thrown out the window

10. A truly good writer is always especially careful to practically eliminate the too-frequent use of adverbs.

11. In my opinion, I think that an author when he is writing something should not get accustomed to the habit of making use of too many redundant unnecessary words that he does not actually really need in order to put his message across to the reader of what he has written.

12. About them sentence fragments. Sometimes all right.

13. Try to not ever split infinitives.

14. Its important to use your apostrophe's correctly.

15. Do not use a foreign term when there is an adequate English quid pro quo. ${ }^{10}$

"Well, sin is interesting," I hear you saying, "but what about the positive? What are the good practices that legal writing should follow?" Again, Justice Laskin assists. In a recent article, he offers instructions on the form and content of factums. "Clear writing remains the foundation for any successful factum, he advises, and offers the following rules of advocacy. They apply just as well to writing learned papers or judgments.

The first rule of advocacy - the cardinal rule, according to Justice Laskin — is to put yourself in the position of your audience; in the case of a factum, the judges. They know nothing of the case. You are intimately familiar with it. What must you tell them to get a favourable outcome on appeal?

Judges too must try to put themselves in the position of their audience. Their task is more complicated than counsel's since they must write for many audiences:

Ibid.

"28 Matters That Writers Ought to Be Appraised Of" in R. LeFlar, ed.. Appellate Judicial Opinions (St. Paul, Minn.: West Publishing, 1974) 194 at 194-95, reproduced in R.J. Aldisert, Opinion Writing (St. Paul: West Publishing, 1990) at 239-40.

Supra note 8 at 3-12. 


$\begin{array}{ll}- & \text { the parties } \\ - & \text { the lawyers } \\ - & \text { other judges } \\ - & \text { academics } \\ - & \text { the press and the public. }\end{array}$

Plain, clear language is the only way to meet the goal of communicating with all these audiences.

Another tip Justice Laskin offers is "point-first writing."'2 Point-first writing puts context before details. It is a valuable tool for advocates. Set out the context in the factum before the details. Describe the context in an overview statement. This helps the court understand the case and provides a framework around which the judges can organize the details. Without context, judges are left to decide the importance of details without knowing their relevance. This does not help counsel's case.

And remember your sentence structure. Long sentences filled with subordinate clauses produce headaches, but little else. In their haste to qualify their statements with such clauses, too many lawyers bury the main idea. Sentences beginning with dependent clauses such as "although," "if" or "even if" will tire readers before they get to the main clause. Put dependent clauses at the end of the sentence, not the beginning. Make important points at the beginning or end of the sentence, not in the middle. And don't be afraid to use a list to make a factum more readable.

Length matters too. Do not assume that judges will be critical of a short factum. Court rules may establish the maximum length of a factum. Too many lawyers interpret this upper limit as their target. Instead, they should say what they need to say. When they have said it, they should stop. The same, need I say, applies to judgments - although too often we judges forget it. And legal articles? Is not conciseness a virtue there too?

I do not argue that we should pay such deference to the rules of writing that they become a straitjacket of grammatically correct but colourless language. Effective legal writing must move beyond simply communicating ideas. It must also convince. Good legal style can be summed up in three words: communication that convinces. It is important to state the facts, law and theory of the case clearly and concisely. But it is equally important to attract the judge to one's thesis - to convince and persuade. So heed Orwell's advice and search for the striking figure of speech. Remember Lord Sankey's metaphor in the Persons Case for the Canadian Constitution: "a living tree capable of growth and expansion." ${ }^{13}$ How economical. How memorable. How enduring.

There is no shortcut to effective writing. Practice will make it easier, but good legal writing is simply hard work. One day, as you prepare a particularly troublesome factum, you will undoubtedly agree with Orwell when he described writing a book as a "horrible,

: Supra note 8 at 4.

13 Edwards v. Canada (A.G.), [1930] A.C. 124 at 136 (P.C.), rev'g Reference as to the meaning of the word "persons" in section 24 of the British North America Act, 1867, [1928] S.C.R. 276. 
exhausting struggle, like a long bout of some painful illness." 14 I don't want to discourage you - Orwell was a bit of a pessimist, after all - but his point about the demands of writing is well taken.

And the work, of course, doesn't end with the writing. All writing requires editing. All editing takes time. You may need to edit several times, looking each time at a different characteristic - accurate case citations, typing errors, grammar, punctuation, tone, headings or sentence length. I frequently go through three or four complete redrafts of reasons for judgment; reorganizing, shortening. Sometimes I abandon a first draft altogether, consigning it to my special high-security waste basket.

At this point, I must digress to make a personal attack on the-time-is-money-assemblyline thinking that has moved from the factory floor - where it belongs - to the legal desk, where it does not. Legal writers must be prepared to throw the product of hours indeed days - into the waste basket. They must be prepared to abandon paths they have started down. They must fight the notion that the bad draft is time wasted. It is not. Legal analysis is an act of exploration. As such, it involves false starts and restarts. Do not be afraid to throw away what you have done and begin again.

And here's the bonus. Good legal writing makes lawyers good oral advocates. When you take the written word and adapt it for your oral presentation, you will find yourself using the same philosophy as in your writing. You will be simple, direct, brief, and convincing. Your aim will be to communicate - to make it as easy as possible for the court to understand you.

Compelling advocacy, like compelling writing, is an art, acquired through writing and rewriting, reading and rereading. I would like to offer you two examples of how not to plead in court. At the turn of the twentieth century, the maverick Calgary publisher Robert (Bob C.) Edwards described - by way of parody, I can only hope - a lawyer pleading a criminal case. Said the lawyer:

If your honour please, I would not for a moment mutilate the majesty of the law nor contravene the avoirdupois of the testimony, but 1 would ask you to focalize your five senses on the proposition I am about to propound to you. In all criminal cases there are three essential elements - the locus in quo, the modus operandi and the corpus delicti. In this case I think I am safe in saying the corpus delicti and the modus operandi are all right, but there is an entire absence of the locus in quo. 1 therefore ask for dismissal of the case. ${ }^{15}$

If you sound like this, or if you think this is how you should sound, you and your clients are both in serious trouble.

Justice Brennan of the United States Supreme Court liked to tell the story of his first criminal trial. He had been appointed to defend a vehicular manslaughter case. An elderly

If G. Orwell, "Why I Write" in Collected Essays (London: Secker \& Warburg, 1961) 435 at 442.

is R. Hamilton \& D. Shields, The Dictionary of Canadian Quotations and Phrases, rev. ed. (Toronto: McClelland and Stewart, 1979) at 516. 
Irish police officer who lived near the defendant agreed to be a character witness. Unfortunately, the young Brennan did not know that he was allowed to prepare a witness to testify. Mr. Brennan's examination of the officer went as follows:

"Sir, are you acquainted with the defendant's reputation for veracity in the vicinage where he resides?"

The officer looked puzzled. Still, he wanted to help. "Well, he is a good driver. l'd say", he volunteered tentatively.

Shaken but undeterred, Brennan repeated his question word for word. This time, the witness simply stared at him. As Brennan began the third time, the judge interrupted.

"Officer, do you know the young man over there?" pointing to the defendant.

"Yes, Your Honor."

"Have you ever known him to lie?"

"Why, no. Your Honor."

"Well, that is what Mr. Brennan has been asking you, but he went to Harvard Law School and has forgotten how to speak English."'"

Some of you here tonight may have been to Harvard Law School, and I would never malign that august institution. Let me say only this. I hope that the clear skies and straight talk of Alberta will encourage you always to avoid pedantic obfuscation and cherish clear communication.

I've enjoyed communicating with you tonight, and look forward to your returning the favour when you appear before the Supreme Court of Canada. 